\title{
Auditor Retention: Auditor and Auditee Factors
}

\author{
Majidah, ${ }^{1 *}$ Dedik Nur Triyanto, ${ }^{2}$ Erika Vivi Andriyani ${ }^{3}$ \\ 1,2,3 Telkom University, Jl. Telekomunikasi, 40257, Bandung, Indonesia
}

\begin{abstract}
Objective -This study aims to examine the influence of auditor and auditee factors on auditor retention.

Methodology/Technique - The analysis unit of this research is manufacturing firms that were listed on the Indonesian Stock Exchange between 2010 and 2014. Using purposive sampling, 54 companies, or 270 observations, were obtained. This research uses a logistic regression; there are 12 outliers in the data that disturb the regression model, hence, the final research data set was 258 .

Findings - The result of the logistic regression analysis shows that auditee and auditor factors can simultaneously explain auditor retention by up to $4 \%$. This partial effect shows that only audit quality affects auditor retention by $57.2 \%$, at a level of significance of less than $=5 \%$. Meanwhile, firm size affects auditor retention by $14.8 \%$, at a significance level of less than $=10 \%$.

Novelty -This research is unique because auditor retention and proxy of audit quality has never been investigated in previous studies.
\end{abstract}

Type of Paper: Empirical

Keywords: Auditee Factors; Auditor Factors; Auditor Retention, Indonesia.

JEL Classification: M4, M42, M49.

\section{Introduction}

Accounting information or financial reports are used by employed to make business decisions (Majidah, Nazar, Muslih \& Anggraeni, 2016). In order for the report to be useful for users, it must be audited by external auditors (Bagherpour, Monroe \& Shailer, 2010). External auditors can provide guarantees for the quality of the auditee's financial reports, to increase stakeholder trust in the company (Ball \& Shivakumar, 2012).

\footnotetext{
* Paper Info: Received: September 02, 2018

Accepted: December 10, 2018

* Corresponding author: Majidah

E-mail: majidah@telkomuniversity.ac.id

Affiliation: Accounting Department, School of Economics and Business, Telkom University, Indonesia
}

To maintain the independence of external auditors, the assignment period of external auditors is limited by Government Regulation No 17/PMK/01/2008 concerning Public Accountant Services, where, in Article 3 
Paragraph 1, it is stated that general audit services are provided for 6 six consecutive financial years by the Public Accountant Office (KAP) and 3 three consecutive financial years by external auditors. Auditor switching can occur where the auditee does not want to be audited by external auditors (auditee factor) or where the external auditor does not want to extend the audit time (auditor factor) (Ismail \& Aliahmed, 2008; Lin \& Liu, 2010).

This study uses auditor retention as the variable of how long the auditor is retained to conduct the audit service. Therefore, the viewpoint of auditor switching with auditor retention is contradictory. However, it is relevant in this study to refer to references on auditor switching. The motivation of this study is to test both auditor and auditee factors affecting auditor retention. This study examines manufacturing firms listed on the Indonesian Stock Exchange. This study is not limited to voluntary or mandatory auditor retention.

\section{Literature Review}

\subsection{Agency Theory}

The relationship between auditees and users of financial reports or stakeholders is associated with agency theory (Jensen \& Meckling, 1976). The quality of information may be low or there may be information asymmetry between the management of an organization and the users of financial information if there is no examination to guarantee whether the information is qualified or not (Paramarini \& Majidah, 2014). The auditor's function is to guarantee the quality of information. Auditees and auditors who carry out their functions according to their duties can minimize the occurrence of voluntary auditor switching, which is able to reduce agency problems and maintain auditor independence.

\subsection{Auditor Factors}

\subsubsection{Audit Opinion and Auditor Retention}

Unqualified opinion has a positive influence on auditor switching (Hudaib \& Cook, 2005). Auditees tend to dislike opinions from unqualified people (Salleh \& Jasmani, 2014). In other words, unqualified opinions have a positive affect on auditor retention.

H1: Auditor opinions have a positive effect on auditor retention.

\subsubsection{Audit Quality and Auditor Retention}

Audit quality is an important factor in selecting auditors to maintain company reputation (Vanstraelen \& Shelleman, 2017). KAPs with a good service reputation with the Public Accountant Office will result in qualified audits, meaning auditees will not switch their auditors (Jackson \& Moldrich, 2008; Firth, Rui \& $\mathrm{Wu}, 2012)$. Therefore, audit quality has a positive effect on auditor retention. The audit quality will be proxied with the earnings surprise benchmark (Carey \& Roger, 2006). If profits exceed the earnings surprise benchmark, the auditors will be unable to disclose indications of window dressing, meaning that the audit is not qualified. However, the losses exceed the earnings benchmark, the auditors will be unable to disclose the indication of 'taking a bath', leading to unqualified audits. Qualified audits refers to an audit where the reported profits or losses do not exceed the earnings benchmark.

H2: Audit quality has a positive effect on auditor retention.

\subsection{Auditee Factors}




\subsubsection{Financial Distress and Auditor Retention}

Financial distress is a condition in which a company experiences financial difficulties (Cohen, Costanzo \& Rossi, 2017). Companies that experience financial difficulties are more likely to replace their auditors (Chen, Chang \& Yen, 2005; Hudaib \& Cook, 2005; Khasharmeh, 2015), because new auditors will increase the trust of the company, and enable the company to obtain more funds for its operations (Chadegani \& Chadegani, 2011).

H3: Financial distress has a negative effect on auditor retention.

\subsubsection{Firm Size and Auditor Retention}

Big companies typically have complex management structures. In this situation, increasing supervision of management can potentially overcome agency problems by retaining qualified auditors (Carcello, Hermanson, Neal \& Riley, 2002; Salehi \& Alinya, 2017). Hence, big companies are more likely to retain qualified auditors to minimize agency costs (Nasser, Wahid, Nazri \& Hudaib, 2006).

H4: Firm Size has a positive effect on auditor retention.

\section{Research Methodology}

The unit of analysis in this study is manufacturing firms listed on the Indonesian Stock Exchange between 2010 and 2014. Based on a purposive sampling method, 54 companies, or 270 observations, were obtained. The results were analyzed using a logistic regression because the dependent variable use a nominal scale. The definitions of the operational variables are described in Table 1.

Table 1. Operational Variables

\begin{tabular}{|c|c|c|c|}
\hline No & Variable & Indicator & Scale \\
\hline \multicolumn{4}{|c|}{ Auditor Factors } \\
\hline 1. & Audit Opinion & $\begin{array}{l}\text { Unqualified Opinion }=1 \\
\text { Besides Unqualified Opinion }=0\end{array}$ & Nominal \\
\hline 2. & Audit Quality & $\begin{array}{c}\text { Earnings Surprise Benchmark; } \\
\begin{array}{c}\mu-\sigma<\mathrm{ROA}<\mu+\sigma ; \text { qualified }=1 \\
\text { ROA }>\mu+\sigma ; \text { unqualified }=0 \\
\text { ROA }<\mu-\sigma ; \text { unqualified }=0\end{array}\end{array}$ & Nominal \\
\hline \multicolumn{4}{|c|}{ Auditee Factors } \\
\hline 3. & Financial Distress & Debt to Equity Ratio & Ratio \\
\hline 4. & Firm Size & Ln Total Assets & Ratio \\
\hline 5. & Auditor Retention & $\begin{array}{c}\text { Not switching auditors } \geqslant 2 \text { years } \\
\text { Auditor Retention }=1 \\
\text { Non Auditor Retention }=0\end{array}$ & Nominal \\
\hline
\end{tabular}


Note: The model of logistic regression in this study is: as follow: Logistic (AudRet) $=\beta 0+\beta 1$ AudOp $+\beta 2 \mathrm{AudQua}+$ $\beta 3$ FinDis $+\beta 4$ Firm size.

\section{Results}

\subsection{Descriptive Statistic}

Table 2. Descriptive Statistic of Variables with Nominal Scale

\begin{tabular}{|c|c|c|c|c|c|c|c|c|}
\hline \multicolumn{4}{|c|}{ Audit Opinion } & \multicolumn{3}{c|}{ Audit Quality } & \multicolumn{3}{c|}{ Auditor Retention } \\
\hline AuditOP & Freq. & Per cent & AuditOP & Freq. & Per cent & AudReten & Freq. & Per cent \\
\hline Unq.Op & 229 & $88.76 \%$ & AudQuality & 165 & $63.95 \%$ & AudReten & 178 & $68.99 \%$ \\
\hline Others & 29 & $11.24 \%$ & AudUnQuality & 93 & $36.05 \%$ & NonAudRet & 80 & $31.01 \%$ \\
\hline Total & $\mathbf{2 5 8}$ & $\mathbf{1 0 0 . 0 0 \%}$ & Total & $\mathbf{2 5 8}$ & $\mathbf{1 0 0 . 0 0 \%}$ & Total & $\mathbf{2 5 8}$ & $\mathbf{1 0 0 . 0 0 \%}$ \\
\hline
\end{tabular}

Table 2 presents the results of the descriptive statistic. From the 270 samples, there are 12 outliers that are excluded from the statistical analysis, thus, the final data set is 258 . Table 2 shows that $88.7 \%$ of manufacturing firms obtained unqualified opinions, $63.95 \%$ of audits are qualified and auditor retention is at $69 \%$. For additional interpretation, $24.81 \%$ of companies obtained unqualified opinions. This has the potential for window dressing or taking a bath. On the other hand, $19.77 \%$ of the companies that obtained unqualified opinions switched auditors.

Table 3. Descriptive Statistics of Variables with Ratio Scale

\begin{tabular}{|c|c|c|c|c|c|}
\hline & $\mathrm{N}$ & Minimum & Maximum & Mean & Std. Deviation \\
\hline FinDistress & 258 & -10.34 & 9,47 & 1.0455 & 1.87977 \\
\hline FirmSize & 258 & 25.08 & 31.70 & 27.9764 & 1.58860 \\
\hline Valid N (listwise) & 258 & & & & \\
\hline
\end{tabular}

Table 3 shows that the average financial distress that is proxied with debt to equity ratio is 1.0455 less than the standard deviation of 1.8797. This means that the financial risk of manufacturing firms is varied. Meanwhile, the average firm size, that is proxied with Ln Total Assets, is of 27.976 higher than the standard deviation of 1.588. This means that the size of manufacturing firms listed on the Indonesian Stock is relatively equal in terms of total assets.

\subsection{Logistic Regression Analysis}


Table 4. Model Summary

\begin{tabular}{|c|c|c|}
\hline -2 Log likelihood & $\begin{array}{c}\text { Cox \& Snell R } \\
\text { Square }\end{array}$ & Nagelkerke R Square \\
\hline $312.116 \mathrm{a}$ & .028 & .040 \\
\hline \multicolumn{2}{|c|}{$\begin{array}{c}\text { a. Estimation terminated at iteration number 4 because } \\
\text { parameter estimates changed by less than .001. }\end{array}$} \\
\hline \multicolumn{2}{|c|}{}
\end{tabular}

The value of nagelkerke $\mathrm{R}$ square is 0.04 , meaning the auditor and auditee factors are able to describe auditor retention by up to $4 \%$.

Table 5. Hosmer-Lemeshow Test

\begin{tabular}{|c|c|c|c|}
\hline Step & Chi-square & $\mathrm{df}$ & Sig. \\
\hline 1 & 4.860 & 8 & .772 \\
\hline
\end{tabular}

The Hosmer-Lemeshow Test, shown in Table 5, describes a significance level of $0.772>5 \%$, meaning that the auditor and auditee factors affect auditor retention simultaneously.

Table 6. Variables in the Equation

\begin{tabular}{|c|c|c|c|c|c|c|c|}
\hline \multicolumn{2}{|c|}{} & B & S.E. & Wald & df & Sig. & Exp(B) \\
\hline \multirow{3}{*}{ Step 1a } & AuditOP & .084 & .427 & .039 & 1 & .844 & 1.088 \\
\cline { 2 - 8 } & AuditQuality & .572 & .281 & 4.134 & 1 & .042 & 1.771 \\
\cline { 2 - 8 } & FirmSize & .148 & .088 & 2.844 & 1 & .092 & 1.160 \\
\cline { 2 - 8 } & FinDistress & .044 & .073 & .365 & 1 & .546 & 1.045 \\
\cline { 2 - 8 } & Constant & -3.814 & 2.489 & 2.348 & 1 & .125 & .022 \\
\hline
\end{tabular}

Note: a. Variable(s) entered on step 1: AuditOP, AuditQuality, FirmSize, FinDistress.

Table 6 shows that only audit quality partially affects auditor retention with a $\beta$ coefficient of $57.2 \%$ and a significance level of $0.042<\alpha=5 \%$. Meanwhile, firm size affects auditor retention with a $\beta$ coefficient of $14.8 \%$, and a significance level of $0.092<\alpha=10 \%$.

\section{Discussion}

The results of the logistic regression statistical analysis indicate that the main determinant factor of auditor retention is audit quality, which is proxied by the earnings surprise benchmark. This shows that qualified auditors are retained in the company according to the audit period, in accordance with government regulations (five years for audit firm). Audit quality can also reduce agency conflict as it is based on the quality of earnings reflected in the earning surprise benchmark, so that the audit opinion provided is consistent with the actual condition of the company. Meanwhile, although the significance level is more than $5 \%$ (less than 10\%), firm size is also a determinant factor of auditor retention. Big companies with a larger 
management base tend to maintain their auditors in accordance with the engagement period to minimize agency costs.

\section{Conclusion}

Based on the descriptive statistics, unqualified opinion, audit quality and auditor retention dominate the data of manufacturing firms listed on the Indonesian Capital Market. The results of the analysis show that audit quality is the main determinant factor of auditor retention. This indicates that qualified auditors are maintained in the company without ignoring the independence of auditors, namely, not exceeding the maximum engagement period in accordance with the regulations. Firm size is another determinant factor of auditor retention, although the effect is not strong. The novelty of this study is the use of the proxy of audit quality with the earnings surprise benchmark associated with auditor retention. Future research may wish to continue this study in a different industry and examine auditor retention with an engagement period of three to five years.

\section{References}

Bagherpour, M., Monroe, G. and Shailer, G. (2010). Auditor Switching in an Increasingly Competitive Audit Market. Working Paper.

Ball, R. J. and Shivakumar, L. (2012). Audited Financial Reporting and Voluntary Disclosure as Complements: A Test of the Confirmation Hypothesis. Journal of Accounting and Economics, 53(6), 136-166.

Carcello, J. V., Hermanson, D. R., Neal, L. T. and Riley, J. A. (2002). Board Characteristics and Audit Fees. Contemporary Accounting Research, 9(3), 365-84.

Carey, P. and Roger, S. (2006). Audi Partner Tenure and Audit Quality. The Accounting Review, 81(3), 653-676.

Chadegani, A. A., Z, M. M. and A, J. (2011). The Determinant Factors of Auditor. International Research, 158-168.

Chen, C. L., Chang, F. H. and Yen, G. (2005). The Information Contents of Auditor Change in Financial Distress Prediction-Empirical Finding from TALEX-Listed Firms. Retrieved August 3, 2018, from www.google.com.

Cohen, S., Costanzo, A. and Rossi, F. M. (2017). Auditors and Early Signals of Financial Distress in Local Governments. Managerial Auditing Journal, 32(3), 234-250.

Firth, M., Rui, O. M. and Wu, X. (2012). How Do Various Forms of Auditor Rotation Affect Audit Quality? Evidence from China. The International Journal of Accounting, 47(1), 109-138.

Hudaib, M. and Cook, T. E. (2005). The Impact of Managing Director Changes and Financial Distress on Audit Qualification and Auditor Switching. Journal and Business Finance and Accounting, 32, 1703-39.

Ismail, S. and Aliahmed, H. (2008). Why Malaysian Second Board Companies Switch Auditors: Evidence of Bursa Malaysia. International Research Journal of Finance and Economics, 13, 123-130.

Jakcson, A. B. and Moldrich, M. (2008). Mandatory Audit Firm Rotation and Audit Quality. Managerial Auditing Journal, 23(5).

Jensen, M. C. and Meckling, W. H. (1976). Theory of The Firm: Managerial Behavior, Agency Costs and Ownership Structure. Journal of Financial Economics, 3(4), 305-360.

Khasharmeh, H. A. (2015). Determinants of Auditor Switching in Bahraini's Listed Companies. European Journal of Accounting, Auditing and Finance Research, 3(11), 73-99.

Lin, Z. J. and Liu, M. (2010). The Determinants of Auditor Switching from The Perspective of Corporate Governance in China. Advances in Accounting, Incorporating Advances in international Accounting Journal., 26, 117-127.

Majidah, Nazar, M. R., Muslih, M. and Anggraeni, G. (2016). Earnings Quality: Corporate Governance Perception Index, Intellectual Capital and Spiritual Values. Advanced Science Letters, 4338-4340.

Nasser, A. A., Wahid, E. A., Syed Mustapha Nazri, S. N. and Hudaib, M. (2006). Auditor-Client Relationship: The Case of Audit Tenure and Auditor Switching in Malaysia. Managerial Auditing Journal, 21(7), 724-737.

Paramarini, S. S. and Majidah. (2014). The Effect of Corporate Governance Mechanism and Audit Quality on Information Asymmetry. ICG2014-International Conference on Governance: Do Governance Implementation Support Sustainable Development?, (1-14). Jakarta.

Salehi, M. and Alinya, A. A. (2017). The Relationship Between Corporate Governance and Audit Switching: Iranian Evidence. International Journal of Law and Management, 673-686. 
Salleh, K., \& Jasmani, H. (2014). Audit rotation and audit report: empirical evidence from Malaysian PLCs over the period of ten years. Procedia-Social and Behavioral Sciences, 145, 40-50.

Vanstraelen, A., \& Schelleman, C. (2017). Auditing private companies: what do we know?. Accounting and Business Research, 47(5), 565-584.

\section{Case Processing Summary}

\section{Case Processing Summary}

\begin{tabular}{llr|r} 
Unweighted Cases $^{\text {a }}$ & $\mathrm{N}$ & \multicolumn{1}{c}{ Percent } \\
\hline Selected Cases & Included in Analysis & 258 & 100,0 \\
\cline { 2 - 4 } & Missing Cases & 0 &, 0 \\
\cline { 2 - 4 } & Total & 258 & 100,0 \\
\hline Unselected Cases & 0 &, 0 \\
\hline Total & 258 & 100,0 \\
\hline
\end{tabular}

a. If weight is in effect, see classification table for the total number of cases. 